\title{
Marine microalgae as a potential source of minerals in fish diets
}

Jaime Fábregas, Concepción Herrero

Departamento de Microbiología, Universidad de Santiago de Compostela, Santiago de Compostela (Spain)

\section{Aquaculture}

Volume 51, Issues 3-4, 15 January 1986, Pages 237-243

Accepted 3 November 1985, Available online 6 October 2003

Doi:10.1016/0044-8486(86)90315-7

\section{Abstract}

The incorporation of powdered marine microalgae in fish diets can substitute, at least in part, for the addition of minerals to the diet. In diets for freshwater fishes, the incorporation of $33 \%$ of powdered marine microalgae can supply some of the mineral element requirements. The incorporation of microalgal powder in diets for marine fishes appears more effective, since lower percentages are needed to cover the mineral requirements. Most mineral needs of turbot can be covered with low percentages of marine microalgal powder in the diet: $3.8 \%$ of Tetraselmis suecica, $5.7 \%$ of Isochrysis galbana, $3.57 \%$ of Dunaliella tertiolecta and $3.9 \%$ of Chlorella stigmatophora. $\mathrm{Mn}$ and Co must, however, be added. Thus, incorporation of small amounts of marine microalgae in diets can replace a mineral mixture. 


\section{Introduction}

Marine microalgae growing naturally in seawater constitute an essential and huge link in the global food chain and global oxygen production (Berend et al., 1980).

The ability of marine microalgae to accumulate trace elements is well documented (Jensen et al., 1974; 1976; Sakaguchi et al., 1981) but very little work on the mineral content of marine microalgae has been done with laboratory cultures, and none has focussed on their utilization as feed. Most of the research on inorganic elements has been confined to osmoregulation (Ginzburg, 1981; Rebhun and Ben-Amotz, 1984), toxicity (Cain et al., 1980; Wong, 1980) and related physiological functions (Azam et al., 1974; Adshead-Simonsen et al., 1981).

Mineral nutrition is one of the most neglected areas in the field of aquaculture (Lall, 1979). Minerals which have demonstrable biological functions, either in elemental form or when incorporated into specific compounds, include calcium, phosphorus, magnesium, sodium, potassium, sulfur, chlorine, iron , copper, cobalt, iodine, manganese, zinc, molybdenum, selenium and fluorine (Nose, 1972). Little, if any, published information exists on the needs of fish, shellfish and molluscs for these minerals. Hence, the mineral mixtures designed for warm-blooded animals have frequently been used in studies on nutrient requirements of fish (Lall, 1979). In recent years, active research in the area of mineral nutrition has been undertaken, specially with freshwater fishes (Tacon and De Silva, 1983), although the mineral requirements of marine fishes remain less known.

Some species of microalgae can be useful sources of minerals for animals in aquaculture systems (Stanley and Jones, 1976) and activated-sludge single-cell protein has been successfully incorporated into pelleted feeds for trout (Tacon, 1979).

Tetraselmis suecica, Isochrysis galbana, Dunaliella tertiolecta and Chlorella stigmatophora are marine microalgae at present widely used in marine aquaculture. These marine micro algae have been recently suggested as a new source of single cell protein (SCP) (Fabregas and Herrero, 1985). We report here the mineral composition, in terms of major and trace elements, of these four microalgae with regard to their use in aquaculture. 


\section{Materials and methods}

Four different marine photosynthetic microalgae were used. Tetraselmis suecica (Prasinophyceae) was isolated from Ria de Arosa waters (N.W. Spain) (Fabregas et al., 1984). Isochrysis galbana (Haptophyceae), Dunaliella tertiolecta and Chlorella stigmatophora (Chlorophyceae) were obtained from The Culture Centre for Algae and Protozoa, Cambridge, England. They were cultured in seawater filtered through a 0.45 $\mu m$ Millipore filter, autoclaved at $120^{\mathrm{a}} \mathrm{C}$ for $20 \mathrm{~min}$ and enriched with $\mathrm{NaNO}_{3}, 2 \mathrm{mM}$; $\mathrm{NaH}_{2} \mathrm{PO}_{4}, 100 \mu M ; \mathrm{ZnCl}_{2} 1 \mu M ; \mathrm{MnCl}_{2} 1 \mu M ; \mathrm{Na}_{2} \mathrm{MoO}_{4}, 1 \mu M ; \mathrm{CoCl}_{3} 0.1 \mu M ; \mathrm{CUSO}_{4}$, $0.1 \mu \mathrm{M}$; ferric citrate, $20 \mu \mathrm{M}$; thiamine, $35 \mu \mathrm{g} / \mathrm{l}$; biotin, $5 \mu \mathrm{g} / \mathrm{l}$; $\mathrm{B}_{12} 3 \mu \mathrm{g} / \mathrm{I}$; EDTA, 26.4 $\mu M$; Tris-HCl 5 mM; pH, 7.6; salinity, 35\%。 (Fabregas et al., 1984).

Cultures were carried out in 10-1 flasks with 9 I of culture medium. All the cultures were maintained in a controlled environmental incubator at $15 \pm 11 \mathrm{C}$ and illuminated with 11 fluorescent lamps (Osram daylight L55/10). A 12: 12 light-dark period was maintained. Cultures were continuously pumped with air at a rate of $151 / \mathrm{min}$ (Fabregas et al., 1985).

The different microalgal species were harvested by centrifugation at the end of the logarithmic phases of growth. The slurries obtained were dehydrated in an oven at $60^{\circ} \mathrm{C}$ for $24-30 \mathrm{~h}$. The dehydrated microalgae were analyzed for phosphorus, calcium, iron, magnesium, cobalt, zinc, copper, manganese, sodium, chloride and potassium contents in ash. Ash was obtained by calcining the microalgae in a muffle oven at $600^{\circ}$ C until all the organic matter was destroyed (AOAC, 1980). The standard procedures described in Furman and Welcher (1966) were used for calcium, phosphorus and chloride. The remaining ions were analyzed in an atomic absorption spectrophotometer. We used a preparative elemental method, valid for determining different elements at the same time (Hughes et al., 1980). Warm $\mathrm{HCl} 6 \mathrm{~N}$ was added to the ashes and the resultant solutions were filtered and diluted with bi-distilled water in order to determine the metallic ions by atomic absorption spectrophotometry, choosing suitable conditions in each case.

\section{Results and discussion}

The mineral composition of the four marine microalgae used is presented in Table 1. In comparison with freshwater algae, marine algae generally have a higher content of inorganic ions, related to their greater osmotic potential (Raven, 1980). This is 
especially marked in the $\mathrm{Cl}$ and Na contents. D. tertiolecta and C. stigmatophora, both Chlorophyceae, show similarities and differences between themselves, but also in comparison with the other two species which belong to other taxonomic groups. Thus, mineral distribution does not appear to be correlated with taxonomy. These results are in general accordance with those of Riley and Roth (1971). On the other hand, the mineral composition of all these microalgae includes all the macro and microelements used in aquaculture, so that a small incorporation of these species into diets can replace a mineral mixture. There is considerable variation in the concentration of certain elements, such as $\mathrm{Cu}$ or $\mathrm{Zn}$, among the different species, whereas the concentration of other elements appears very similar. This characteristic could allow us to choose different mixtures of marine microalgae in order to cover specific mineral requirements in aquaculture, taking into account that some microalgae are easier to culture than others and, in addition, that the trace metal content of microalgae could be increased by increasing the concentration of metals in the medium in which the organisms are grown (Riley and Roth, 1971). Therefore, data are correct as such, but represent only the composition obtained under particular growth conditions.

TABLE 1

\begin{tabular}{lcccc}
\multicolumn{4}{l}{ Content of mineral elements in different marine microalgae, on dry weight basis } \\
\hline & T. suecica & I. galbana & D. tertiolecta & C. stigmatophora \\
\hline $\mathrm{P}(\%)$ & 0.65 & 1.02 & 0.73 & 0.64 \\
$\mathrm{Ca}(\%)$ & 2.08 & 1.62 & 2.09 & 1.51 \\
$\mathrm{Na}(\%)$ & 1.04 & 0.72 & 0.92 & 0.98 \\
$\mathrm{~K}(\%)$ & 1.20 & 0.56 & 0.74 & 1.12 \\
$\mathrm{Cl}(\%)$ & 3.72 & 5.08 & 2.42 & 2.45 \\
$\mathrm{Fe}(\%)$ & 0.10 & 0.36 & 0.20 & 0.18 \\
$\mathrm{Mg}(\%)$ & 0.78 & 1.15 & 0.63 & 0.78 \\
$\mathrm{Zn}(\%)$ & 0.15 & 0.06 & 0.03 & 0.03 \\
$\mathrm{Mn}(\mathrm{ppm})$ & 47.49 & 40.47 & 56.51 & 40.46 \\
$\mathrm{Co}(\mathrm{ppm})$ & 5.53 & 10.51 & 5.80 & 7.81 \\
$\mathrm{Cu}(\mathrm{ppm})$ & 652.00 & 204.00 & 65.00 & 108.00
\end{tabular}

Use of unicellular algae as food for warm water fish was considered in a number of studies conducted on small samples in aquaria or tanks. Most of the experiments showed favourable results, the freshwater fish utilizing the microalgae quite effectively (Stanley and Jones, 1976).

On the basis of different feeding trials it was concluded that activated sludge single-cell protein (ASCP) can be successfully incorporated into pelleted feeds for trout, at dietary levels of up to $33 \%$ (Tacon, 1979). The mineral composition of this ASCP is very similar to those of the marine microalgae described here. The ASCP has a greater content of $\mathrm{Fe}$ and $\mathrm{Mn}$, whereas any of the four marine microalgae studied contain 
higher concentrations of $\mathrm{Mg}, \mathrm{K}, \mathrm{Na}$ and $\mathrm{Zn}$. The remaining metals are present in similar concentrations.

TABLE 2

Dietary requirements for mineral elements of different fishes, and percentage of marine microalgae in diet that cover each requirement

\begin{tabular}{|c|c|c|c|c|c|c|}
\hline \multirow[b]{2}{*}{ Species } & \multirow[b]{2}{*}{ Element } & \multirow{2}{*}{$\begin{array}{l}\text { Dietary } \\
\text { requirement }\end{array}$} & \multicolumn{4}{|c|}{$\%$ of marine microalgae in diet } \\
\hline & & & T. suecica & 1. galbana & D. tertiolecta & C. stigmatophora \\
\hline \multirow{4}{*}{$\begin{array}{l}\text { Anguilla } \\
\quad \text { japonica }\end{array}$} & $P^{\prime}$ & $2.9 \mathrm{~g} / \mathrm{kg}$ & 44 & 28 & 41 & 45 \\
\hline & $\mathrm{Ca}^{1}$ & $2.7 \mathrm{~g} / \mathrm{kg}$ & 13 & 16 & 13 & 18 \\
\hline & $\mathrm{Fe}^{2}$ & $0.17 \mathrm{~g} / \mathrm{kg}$ & 16 & 5 & 8 & 9 \\
\hline & $\mathrm{Mg}^{2}$ & $0.4 \mathrm{~g} / \mathrm{kg}$ & 6 & 3.4 & 6 & 5 \\
\hline \multirow{5}{*}{$\begin{array}{r}\text { Cyprinus } \\
\text { carpio }\end{array}$} & $P^{3}$ & $6-7 \mathrm{~g} / \mathrm{kg}$ & 92 & 51 & 85 & 93 \\
\hline & $\mathrm{Mg}^{4}$ & $0.4-0.5 \mathrm{~g} / \mathrm{kg}$ & 5.8 & 3.5 & 6 & 5.1 \\
\hline & $\mathrm{Zn}^{5}$ & $15-30 \mathrm{mg} / \mathrm{kg}$ & 12 & 3.7 & 7.5 & 7.6 \\
\hline & $\mathrm{Cu}^{6}$ & $3 \mathrm{mg} / \mathrm{kg}$ & 0.4 & 1.5 & 4.6 & 2.7 \\
\hline & $\mathrm{Mn}^{6}$ & $12-13 \mathrm{mg} / \mathrm{kg}$ & 25 & 30 & 21 & 30 \\
\hline \multirow{5}{*}{$\begin{array}{l}\text { Salmo } \\
\quad \text { gairdneri }\end{array}$} & $\mathrm{P}^{7}$ & $7-8 \mathrm{~g} / \mathrm{kg}$ & 100 & 60.8 & 100 & 100 \\
\hline & $\mathrm{Mg}^{7}, 8$ & $0.5-0.7 \mathrm{~g} / \mathrm{kg}$ & 7.3 & 4.3 & 7.9 & 6.4 \\
\hline & $\mathrm{Zn}^{9}$ & $5-30 \mathrm{mg} / \mathrm{kg}$ & 1.2 & 3.7 & 7.5 & 7.6 \\
\hline & $\mathrm{Cu}^{6}$ & $3 \mathrm{mg} / \mathrm{kg}$ & 0.46 & 1.5 & 4.6 & 2.7 \\
\hline & $\mathrm{Mn}^{6}$ & $12-13 \mathrm{mg} / \mathrm{kg}$ & 25.5 & 30 & 21.4 & 30 \\
\hline \multirow{11}{*}{$\begin{array}{l}\text { Scophthalmus } \\
\text { maximus }\end{array}$} & $\mathrm{P}$ & $0.25 \mathrm{~g} / \mathrm{kg}$ & 3.8 & 2.45 & 3.57 & 3.9 \\
\hline & $\mathrm{Ca}$ & $0.45 \mathrm{~g} / \mathrm{kg}$ & 2.16 & 2.77 & 2.15 & 2.98 \\
\hline & $\mathrm{Fe}$ & $0.025 \mathrm{~g} / \mathrm{kg}$ & 2.4 & 0.7 & 1.23 & 1.35 \\
\hline & $\mathrm{Mg}$ & $0.039 \mathrm{~g} / \mathrm{kg}$ & 0.5 & 0.33 & 0.61 & 0.5 \\
\hline & $\mathrm{K}$ & $0.32 \mathrm{~g} / \mathrm{kg}$ & 2.66 & 5.7 & 4.3 & 2.8 \\
\hline & $\mathrm{Na}$ & $0.072 \mathrm{~g} / \mathrm{kg}$ & 0.75 & 1 & 0.78 & 0.70 \\
\hline & $\mathrm{Cl}$ & $0.050 \mathrm{~g} / \mathrm{kg}$ & 0.13 & 0.09 & 0.20 & 0.20 \\
\hline & $\mathrm{Cu}$ & $1.2 \mathrm{mg} / \mathrm{kg}$ & 0.21 & 0.62 & 1.95 & 1.17 \\
\hline & $\mathrm{Zn}$ & $8 \mathrm{mg} / \mathrm{kg}$ & 0.45 & 1.38 & 2.76 & 3.18 \\
\hline & $\mathrm{Mn}$ & $5 \mathrm{mg} / \mathrm{kg}$ & 9.4 & 11.05 & 7.94 & 11.09 \\
\hline & Co & $1.9 \mathrm{mg} / \mathrm{kg}$ & 30 & 18 & 32 & 24 \\
\hline
\end{tabular}

${ }^{a}$ The mineral requirements are not known; data are based on the different mineral mixtures of the diets for turbots (Adron et al., 1976;1978; Mahajan and Agrawal, 1980).

'Arai et al., 1974; ${ }^{2}$ Nose and Arai, $1979 ;{ }^{3}$ Ogino and Takeda, 1976; ${ }^{4}$ Ogino and Chiou, 1976; ${ }^{5}$ Ogino and Yang, 1979a; ${ }^{6}$ Ogino and Yang, 1980; ' Ogino and Takeda, 1978; ${ }^{8} \mathrm{Knox}$ et al., 1981; ${ }^{9}$ Ogino and Yang, $1979 \mathrm{~b}$.

Considering the mineral requirements of some cultured freshwater fish species (Table 2), the incorporation of one or more of these microalgae into diets for these fishes at a level of 33\% (as for the ASCP) can supply all their mineral requirements except that of phosphorus, for which large quantities of microalgae would be needed.

As can be seen in Table 2, these marine microalgae could be useful for covering the $\mathrm{Cu}$ and $\mathrm{Mg}$ needs of freshwater fishes and, probably, for other microelements which have not been studied. To meet the requirements of the remaining minerals, incorporation of the algae at dietary levels higher than $5 \%$ is needed, and such additions could influence the final formulation of the diet, since constituents of the marine micro algae other than minerals are included. 
If we consider the mineral composition of commercial fish feeds instead of the mineral requirements, higher percentages of micro algae would be needed in the diets, since the concentrations of certain elements, including $\mathrm{Zn}, \mathrm{Mn}, \mathrm{Cu}$ and $\mathrm{Co}$, are considerably higher in commercial fish feeds than those normally recommended (Tacon and De Silva, 1983).

In contrast to freshwater fishes, the mineral requirements of cultured marine fishes are not known. However, considering the different mineral mixtures of the basal diets for turbot (Scophthalmus maximus) (Adron et al., 1976, 1978; Mahajan and Agrawal, 1980 ), it can be shown that incorporation into the diets of small amounts of the marine microalgae studied can substitute in part for these mineral mixtures. Mineral needs of turbot can be met by low percentages of marine microalgae in the diets: $3.8 \%$ of $T$. suecica, $5.7 \%$ of 1 . galbana, $3.5 \%$ of $D$. tertiolecta and $3.9 \%$ of C. stigmatophora (Table 2), except for $\mathrm{Mn}$ and Co which must be added. Nevertheless, we are working with the concentration of these elements in the mineral mixtures used and not with the exact requirements for these elements. If the $\mathrm{Mn}$ and Co requirements were known, it is very likely that they would be lower than the amounts supplied in mineral mixtures, and that it would be possible to supply them with low quantities of microalgae, since, as has been mentioned above, the mineral contents of the mixtures used generally surpass the dietary requirements.

There are great differences in the amounts of microalgae to be added to diets for freshwater and marine fishes. The requirements for mineral elements are lower in marine than in freshwater species because marine fishes have the ability to absorb certain minerals from the surrounding water as well as from the food ingested (Tacon and De Silva, 1983).

Another interesting aspect in the use of marine microalgae as a source of minerals is that incorporation of $5 \%$ in the diet also results in a protein supply between 2 and $2.7 \%$, since the protein content of these species is between 39 and $54 \%$ of the dry weight (Fabregas and Herrero, 1985).

\section{Acknowledgements}

This work was supported by a grant from the Dirección General de Ordenación Pesquera, Ministerio de Agricultura, Pesca y Alimentacion, Madrid, Spain. Thanks are due to J. Abalde and B. Cabezas for their cooperation. 


\section{References}

Adron, J.W., Blair, A., Cowey, C.B. and Shanks, A.M., 1976. Effects of dietary energy level and dietary energy source on growth, feed conversion and body composition of turbot (Scophthalmus maxim us). Aquaculture, 7: 125-132.

Adron, J.W., Knox, D. and Cowey, C.B., 1978. Studies on the nutrition of marine flatfish. The piridoxine requirement of turbot (Scophthalmus maximus). Br. J. Nutr., 40: 261.

Adshead-Simonsen, P.C., Murray, G.E. and Kushner, D.J., 1981. Morphological changes in the diatom Tabelaria flocculosa induced by very low concentration of cadmium. Bull. Environ. Contam. Toxicol., 26: 745-748.

AOAC, 1980. Official Methods of Analysis, 13th Edn. Association of Official Agricultural Chemists, Washington, DC.

Arai, S., Nose, T. and Kawatsu, H., 1974. Effects of mineral supplemented to a fish meal diet on growth of eel, Anguilla japonica. Bull. Freshwater Fish. Res. Lab. (Tokyo), 24: 95-100.

Azam, F., Hemmingsen, B.B. and Volcani, B.E., 1974. Role of silicon on diatom metabolism. V. Silicic acid transport and metabolism in the heterotrophic diatom Nitzschia alba. Arch. Microbiol., 97: 103-114.

Berend, J., Simovitch, E. and Ollian, A., 1980. Economical aspects of algal animal food production. In: G. Shelef and C.J. Soeder (Editors), Algae Biomass. Production and Use. Elsevier/North Holland Biomedical Press, Amsterdam, pp. 799-818.

Cain, R., Paschal, D.e. and Hayden, C.M., 1980. Toxicity and bioaccumulation of cadmium in the colonial green alga Scenedesmus obUquus. Arch. Environ. Contam. Toxicol., 9: 9-16.

Fabregas, J. and Herrero, C., 1985. Marine microalgae as a potential source of single cell protein (SCP). App. Microbiol. Biotechnol., 23: 110- 113.

Fabregas, J., Abalde, J., Herrero, C., Cabezas, B. and Veiga, M., 1984. Growth of the marine microalga Tetraselmis suecica in batch cultures with different salinities and nutrient concentrations. Aquaculture, 42: 207-215.

Fabregas, J., Herrero, C., Cabezas, B. and Abalde, J., 1985. Mass culture and biochemical variability of the marine microaiga Tetraselmis suecica Kylin (Butch) with high nutrient concentrations. Aquaculture, 49: 231- 244.

Furman and Welcher (Editors), 1966. Standard Methods of Biochemical Analysis. $6^{\text {th }}$ Edn., Vols. 1-3. Princeton, NJ. 
Ginzburg, M., 1981. Mesurements of ion concentrations in Dunaliella parua subjected to hypertonic shock. J. Exp. Bot., 32 (127): 337-340.

Hughes, J.T., CZQchanska, Z., Pickston, L. and Hove, E.L., 1980. The nutritional composition of some New Zealand marine fish and shellfish. N.Z. J. Sei., 23: 43-5l.

Jensen, A. t Rystad, B. and Melsom, M., 1974. Heavy metal tolerance of marine phytoplankton.I. The tolerance of three algal species to zinc in coastal sea waters. J. Exp. Mar. Biol. Ecol., 15: 145-157.

Jensen, A., Rystadt, B. and Melsom, M., 1976. Heavy metal tolerance of marine phytoplankton. II. Copper tolerance of three species in dialysis and batch cultures. J. Exp. Mar. Biol. Ecol., 22: 249-256.

Knox, D., Cowey, C.B. and Adron, J.W., 1981. Studies on the nutrition of salmonid fish. The magnesium requirement of rainbow trout Salmo gairdneri. Br. J. Nutr., 45:137-148.

LaB, S.P., 1979. Minerals in finfish nutrition. In: J.E. Halver and K. Tiews (Editors), Finfish Nutrition and Fishfeed Technology. Vo!. I. Heenemann. Berlin, pp. 85-97.

Mahajan, C.L. and Agrawal, N.K., 1980. The role of vitamin C in calcium uptake by fish. Aquaculture, 19: 287-294.

Nose, T., 1972. Mineral requirements. Suisan Zoshoku, 20: 289-300.

Nose, T. and Arai, S., 1979. Recent advances in studies on mineral nutrition of fish in Japan. In: T.V.R. Pillay and W.A. Dill (Editors), Advances in Aquaculture. Fishing News Books, Farnham, Surrey, pp. 584-590.

Ogino, C. and Chiou, J.Y., 1976. Mineral requirements of fish. II. Magnesium requirement of carp. Bull. Jpn. Soc. Sci. Fish., 42: 71-75.

Ogino, C. and Takeda, H., 1976. Mineral requirements of fish. III. Calcium and phosphorus requirements in carp. Bull. Jpn. Soc. Sci. Fish., 42: 793-799.

Ogino, C. and Takeda, H., 1978. Requirements of rainbow trout for dietary calcium and phosphorus. Bull. Jpn. Soc. ScL Fish., 44: 1019-1022.

Ogino, C. and Yang, G.Y., 1979a. Requirements of carp for dietary zinc. Bull. Jpn. Soc. Sci Fish., 45: 967-969.

Ogino, C. and Yang, G.Y., 1979b. Requirements of rainbow trout for dietary zinc. In: J.E. Halver and K. Tiews (Editors), Finfish Nutrition and Fishfeed Technology. Vol. II Heenemann, Berlin, pp. 105-111. 
Ogino, C. and Yang, G.Y., 1980. Requirements of carp and rainbow trout for dietary manganese and copper. Bull. Jpn_Soc. Sci. Fish., 46: 455-458.

Raven, J.A., 1980. Nutrient transport in microalgae. Adv. Microb. Physiol., 21: 48-220.

Rebhun, S. and Ben-Amotz, A., 1984. The distribution of cadmium between the marine alga Chlorella stigmatophora and seawater medium. Water Res., 18 (2): 173-178.

Riley, J.P. and Roth, I., 1971. The distribution of trace elements in species of phytoplankton grown in culture. J. Mar. Biol. Assoc. U.K., 51: 63-72.

Sakaguchi, T., Nakajima, A. and Horikoshi, T., 1981. Studies on t he accumulation of heavy metal elements in biological systems. XVIII. Accumulation of molybdenum by green microalgae. Appl. Microbiol. Biotechnol., 12: 84-89.

Stanley, J.G. and Jones, J.B., 1976. Feeding algae to fish. Aquaculture, 7: 219-223.

Tacon, A.G.J., 1979. The use of activated-sludge single-cell protein (ASCP) derived from the treatment of domestic sewage in trout diets. In: J.E. Halver and K. Tiews (Editors), Finifish Nutrition and Fishfeed Technology. Vo!. n. Heenemann, Berlin, pp. 249-267.

Tacon, A.G.J. and De Silva, S.S., 1983. Mineral composition of some commercial fish feeds available in Europe. Aquaculture, 31:11-20.

Wong, M.H., 1980. Toxic effects of cobalt and zinc to Chlorella pyrenoidosa (26) in soft and hard water. Microbios, 28: 19-25. 